\title{
Kamila Miłkowska-Samul
}

Szkoła Wyższa Psychologii Społecznej

https://doi.org/10.18778/1733-8069.9.2.08

\section{Emocje a skandal polityczny. O sposobach wykorzystania emocji w dyskursie politycznym}

Abstrakt Celem artykułu jest pokazanie, jakie emocje, w jaki sposób i w jakim celu są wyrażane w ramach dyskursu politycznego, w szczególnym kontekście skandalu politycznego. W świetle wciąż następujących zmian w sposobie uprawiania polityki - związanych w znacznym stopniu z wpływem mediów masowych, Internetu - wyrażanie emocji i kierowanie nimi stanowią jedno z podstawowych narzędzi życia politycznego. Personalizacja polityki, jej mediatyzacja i sensacjonalizacja sprawiaja, iż rola emocji w walce o poparcie i władzę jest równie istotna, jak kompetencji i merytorycznej wiedzy. Skandal natomiast jest momentem, w którym dochodzi do szczególnej koncentracji emocji, dzięki czemu ogniskuje on pewne mechanizmy walki o władzę przy użyciu takich uczuć, jak: emocjonalizacja przekazu jako narzędzie perswazji politycznej, emocje w odbiorze, jak i w kształtowaniu wizerunku. Rozważania te oparte są na przykładzie życia politycznego współczesnych Włoch i skandalu związanego z premierem Silvio Berlusconim, który stanowi doskonałą egzemplifikację tematyki emocji w życiu publicznym.

Słowa kluczowe dyskurs polityczny, skandal, emocje, władza, kapitał symboliczny, reputacja, retoryka, krytyczna analiza dyskursu

Kamila Miłkowska-Samul, dr nauk humanistycznych w zakresie językoznawstwa, mgr socjologii, pracuje w Katedrze Italianistyki SWPS. Jest autorką książki La persuasione nella comunicazione politica in Italia e in Polonia (2011). Jej główne obszary zainteresowania to socjolingwistyka, pragmatyka językowa oraz retoryka. Interesuje się zwłaszcza tematyką języka polityki i perswazji, ale również agresją językową oraz problematyką gender w języku.

Dane adresowe autorki:

Katedra Italianistyki

Wydział Kulturoznawstwa i Filologii

Szkoła Wyższa Psychologii Społecznej

ul. Chodakowska 19/31, 03-815 Warszawa

e-mail: kamila.milkowska-samul@swps.edu.pl
Tiewątpliwie siła, z jaką na przełomie 2010 i 2011 skandal związany z włoskim premierem Silvio Berlusconim i nastoletnią Ruby przetoczył się przez światowe media oraz skala reakcji opinii publicznej, nie tylko we Włoszech, były bardzo istotną przesłanką, która skłoniła mnie do podjęcia tematyki skandalu politycznego i roli emocji w jego przebiegu.

Jednak sensacyjny charakter doniesień, naruszające pewne tabu wydarzenia nie były wyłącznym powodem mojego zainteresowania tą problematyką włoski skandal stanowi doskonałą egzemplifikację mechanizmów walki o władzę i dynamiki skandalu politycznego w ogóle. Obserwacja rozwijającej się na bieżąco sytuacji pozwoliła na dostrzeżenie sposobów wykorzystania sytuacji skandalu w doraźnej walce politycznej oraz roli, jaką odgrywają w tym kontekście emocje. Właśnie w związku z ich wyjątkowym natężeniem, które powoduje wyjaskrawienie opinii i reakcji, mechanizmy walki politycznej i skandalu stają się bardziej czytelne.

Jednocześnie nie można nie zauważyć, iż główny bohater skandalu stanowiącego punkt wyjścia tych rozważań to niezwykle barwna postać, polityk o rzadkiej charyzmie i wielkim talencie retorycznym, choć nader często wzbudzający kontrowersje swoimi wypowiedziami, postępowaniem i decyzjami politycznymi. Silvio Berlusconi, czterokrotny premier, dobrze prosperujący przedsiębiorca, oskarżony o korupcje i kontakty z mafia, niewierny mąż jest jak soczewka, która skupia istotne zjawiska współczesnej polityki oraz, szerzej, tendencje $\mathrm{w}$ dyskursie publicznym, zdominowanym przez dyktat oglądalności, popularności, wszechobecności, narzucony przez środki masowego przekazu. Przez to sam Berlusconi staje się wystarczającą inspiracją dla naukowych dociekań.

Dla porządku pragnę przypomnieć najważniejsze fakty dotyczące skandalu „Ruby-gate”, jak ochrzciła go włoska prasa, który, niczym afera Watergate, nie pozostanie bez wpływu na włoską scenę polityczną. Istotą skandalu, a zarazem oskarżenia sformułowanego przez włoską prokuraturę, jest korzystanie z nielegalnej prostytucji nieletnich oraz nadużycie władzy przez urzędującego premiera Włoch. Silvio Berlusconi miał interweniować na policji w sprawie zatrzymanej za kradzież nieletniej Ruby, podając nieprawdziwe informacje, jakoby była to krewna prezydenta Egiptu Hosni Mubaraka, którą w celu uniknięcia skandalu dyplomatycznego należy natychmiast zwolnić. Pod wpływem tych nacisków dziewczyna została wypuszczona z aresztu pod kuratelę Nicole
Minetti, radnej Lombardii, współpracownicy Berlusconiego. W wyniku równoległego śledztwa w sprawie korzystania z prostytucji wśród mediolańskich elit pojawiły się także oskarżenia o nielegalny charakter stosunków nieletniej Ruby z Berlusconim, często biorącej udział w hucznych przyjęciach organizowanych w willi premiera w Arcore pod Mediolanem, za co otrzymywała wynagrodzenie. Włoska prasa, $\mathrm{w}$ oparciu między innymi o podsłuchy rozmów telefonicznych, od października 2010 dostarczała sensacyjnych informacji o skandalicznym charakterze przyjęć u premiera, ich bywalcach oraz zamiłowaniu Berlusconiego do młodych kobiet.

Z tego skrótowego przedstawienia sytuacji wyraźnie widać, iż skandal z Ruby jest skandalem politycznym dwojakiego rodzaju, $\mathrm{z}$ jednej strony jest to bez wattpienia skandal obyczajowy, wynikający z naruszenia społecznie przyjętych zasad i wartości poprzez zachowania, takie jak niewierność małżeńska, korzystanie z prostytucji, utrzymywanie kontaktów seksualnych z nieletnimi, zaś z drugiej strony mamy tu do czynienia ze skandalem związanym z nadużyciem władzy: wykorzystywaniem zajmowanej pozycji i stanowiska do czynów niezgodnych z prawem.

Takie ujęcie analizowanej sytuacji jest możliwe dzięki przywołaniu rozważań brytyjskiego socjologa Johna B. Thompsona (2010) na temat skandalu politycznego w ogóle, jego typów i funkcji, które stanowić będą punkt wyjścia poniższych przemyśleń. W tej perspektywie skandal widziany jest jako sytuacja walki o kapitał symboliczny (Bourdieu, Passeron 2006) potrzebny do sprawowania władzy, który w dużej mierze może być rozumiany jako reputacja, twarz (Goffman 2006). Mechanizm wykorzystania skandalu jako narzędzia w walce politycznej według Thompsona omówiony zostanie poniżej. 
Nie ulega wątpliwości, iż podstawową sferą uprawiania polityki jest sfera języka (Dobek-Ostrowska, Fras, Ociepka 1999; Fras 2005; Santulli 2005), dlatego też zagadnienie roli emocji w komunikacji politycznej, a konkretnie w przypadku skandalu politycznego, zostanie poruszone przy użyciu narzędzi pochodzących z językoznawstwa oraz retoryki. Mam tu szczególnie na myśli nurt pragmatyczny powstały wokół teorii aktów mowy zaproponowanej przez J. L. Austina (1962), a rozwiniętej między innymi przez J. Searle'a (1969), H. P. Grice'a (1980), która podkreśla interakcyjny wymiar komunikacji, koncentrując się na języku w użyciu, języku jako działaniu. Austinowskie (1962: 100-102) rozróżnienie aktu mowy na lokucję (wypowiadane słowa), illokucję (wyrażenie pewnej intencji) i perlokucję (rzeczywiste wywołanie określonego skutku u odbiorcy) pozwala na ujęcie celów, zamiarów nadawcy (a więc zrozumienie czemu służą emocje w wypowiedzi politycznej), z kolei instrumentarium retoryczne daje możliwość zidentyfikowania środków językowych, poprzez które intencje te są realizowane, mechanizmów ujawniania emocji i nadawania im siły oddziaływania.

Jednakże pragmalingwistyka i retoryka są tylko narzędziami, jako że opis lingwistyczny nie jest w tym tekście celem samym w sobie. Rozważania tu przedstawione mieszczą się $\mathrm{w}$ szeroko pojętym nurcie badań jakościowych (por. Konecki 2005), stawiając sobie za cel próbę opisu i zrozumienia mechanizmu wykorzystania emocji w skandalu politycznym przy pomocy analizy wypowiedzi uczestników włoskiego życia politycznego, a główną ramą spajającą tekst jest krytyczna analiza dyskursu, rozumiana jako perspektywa oglądu tekstów i wypowiedzi w kontekście, a nie spójny, homogeniczny system technik badawczych (por. Horolets 2006: 69). Choć sam ter- min dyskurs, jak i wiążąca się z nim szkoła krytycznej analizy dyskursu, obarczone są wieloznacznościa (przez co budzą niepokój niektórych badaczy, por. Szacki 2002: 905), stanowią one podstawową inspirację badawczą dla niniejszego tekstu, w szczególności chodzi tu o prace badaczy dyskursu, takich jak N. Fairclough (1989), J. Potter, M. Wetherell (1987) czy T. van Dijk (2001). Warte podkreślenia jest tutaj postrzeganie języka, komunikacji jako działania, narzędzia zdobywania i utrzymywania władzy, myśl tę tak ujmują Potter i Wetherell: „dyskurs traktowany jest jako potężne, ukierunkowane na działanie medium, a nie neutralny kanał przekazu informacji" (1987: 160 [tłum. własne]).

Podobnie widzi rolę języka i krytycznej analizy dyskursu N. Fairclough, który jej cele ujmuje w następujący sposób:

pierwszy ma charakter teoretyczny: chodzi o próbę skorygowania szeroko rozpowszechnionego niedocenienia wagi języka w tworzeniu, utrzymywaniu i zmienianiu społecznych relacji władzy. Drugi cel ma wymiar bardziej praktyczny, jest nim spowodowanie wzrostu świadomości znaczenia języka, który przyczynia się do dominacji jednych ludzi nad innymi, gdyż świadomość stanowi pierwszy krok do wyzwolenia. (1989: 1 [tłum. własne])

Z kolei T. van Dijk podkreśla złożony charakter dyskursu rozumianego jako struktura i proces, a mianowicie eksponuje społeczny i poznawczy wymiar dyskursu, podkreśla, iż formy językowej komunikacji powiązane są ściśle ze społecznym kontekstem i przekazywaniem przekonań w interakcji (van Dijk 2001: 14). W tym tekście analiza konkretnych wypowiedzi z punktu widzenia realizowanych aktów mowy, typu siły illokucyjnej i środków retorycznych, które temu służa, również ma na celu uwypuklenie momentu przekazywania idei, przekazywania wartościowań.
Rola jaką w tym procesie odgrywają emocje, a właściwie ich ekspresja, jest nie do przecenienia. Obszerna i zróżnicowana problematyka emocji widzianych z perspektywy socjologicznej (por. Stets, Turner 2007; Turner 2009) ograniczona jest $\mathrm{w}$ tym tekście do analizy pragmatycznych i retorycznych aspektów ekspresji emocji w sytuacji skandalu, która stanowi osadzenie społeczne decydujące o ich rodzaju, powodach i sposobach wyrażania oraz funkcji jaką mogą odgrywać. Analizie poddane zostaną przede wszystkim emocje negatywne, takie jak oburzenie i wstyd oraz ich celowe wykorzystanie w sytuacji skandalu politycznego. Teoretycznym punktem wyjścia jest tu podejście dramaturgiczne w klasycznym ujęciu E. Goffmana (2006; 2008), a także dramaturgiczna teoria emocji w rozumieniu A. R. Hochschild (2009, por. też Turner 2010: 495-496), która zwraca uwagę na kontekst kulturowy, narzucający rodzaj i sposoby odczuwania i okazywania emocji. Hochschild twierdzi, iż obowiązujące ideologie emocjonalne, składające się na szerszą kulturę emocji danej społeczności, realizowane $\mathrm{w}$ postaci reguł odczuwania i wyrażania emocji, sprawiają, iż jednostki muszą kontrolować uczucia, pracować nad emocjami, tak by przygotować odpowiednią prezentację samego siebie. $\mathrm{W}$ obszarze polityki, w tym $\mathrm{w}$ przypadku skandalu, mechanizmy zarządzania emocjami nabierają szczególnego znaczenia w kontekście walki o władzę przy pomocy perswazji i pozytywnej autoprezentacji. W dalszej części postaram się pokazać, w jaki sposób celowe nasycenie przekazu emocjami jest warunkowane przez kontekst (polityczny) oraz jaką rolę odgrywa w kształtowaniu pożądanego wizerunku samego siebie.

Spojrzenie na niejako rewers relacji władzy i emocji stanowi z kolei koncepcja Theodore'a D. Kempera (2005), jednego z pionierów socjologii emocji, który wskazuje, iż emocje powstają na bazie relacji społecznych, a zwłaszcza relacji „władzy" i „statusu”. Emocje determinowane są przez sytuacje, które nadają lub odbierają jednostkom władzę wydawania poleceń, prestiż, poszanowanie (por. Turner 2010: 510): utrata władzy budzi przede wszystkim smutek, złość i strach, natomiast awans w hierarchii władzy jest źródłem szczęścia/satysfakcji.

Te wstępne uwagi pozwalają określić ramy teoretyczne, w jakich będziemy się obracać, analizując zagadnienie wykorzystania emocji $\mathrm{w}$ skandalu politycznym, a które znajdą swoje rozwinięcie $\mathrm{w}$ dalszej części tekstu. Nie może również pozostać bez komentarza kwestia roli mediów masowych, które zapośredniczają a także kształtują komunikację, zwłaszcza w sferze publicznej (Goban-Klas 2004; 2005; Fras 2005: 45-46) i stanowią główne forum, na którym toczy się dyskurs polityczny, a w przypadku skandalu odgrywają kluczową rolę (Thompson 2010).

\section{Uwagi metodologiczne}

Materiał badawczy dla tego artykułu stanowią wypowiedzi uczestników włoskiej sceny politycznej dla mediów, stanowiące reakcję na sytuację skandalu politycznego z udziałem Berlusconiego i Ruby.

Źródłem materiału badawczego są wybrane media włoskie (internetowe wydania dzienników i portale informacyjne), analizowane w okresie od października 2010 do czerwca 2011. Wstępna selekcja tekstów poddanych analizie polegała na wyodrębnieniu artykułów cytujących wypowiedzi uczestników życia politycznego Włoch na temat skandalu z Ruby, które zawierały odniesienie do reakcji, w tym zwłaszcza reakcji ujawniających nastawienie emocjonalne. Etap ten można odnieść do procedury kodowania (coding) w ujęciu J. Pottera i M. Wetherell (1987: 167), 
które nie jest analizą samą w sobie, lecz ma na celu ujęcie całości korpusu w kategorie, którymi badacz będzie w stanie się posługiwać (squeeze the unwieldy body of discourse into manageable chunks, por. też Horolets 2006), kategorie zaś, które tu zostały użyte, to emocje w ogóle i ich poszczególne rodzaje: oburzenie, potępienie, wstyd, współczucie, sympatia i tak dalej. Ostatecznie, refleksje nad emocjami jako rodzajem strategii dyskursywnej oparte są na szczegółowej analizie 8 tekstów, zgadzam się bowiem z opinią J. Pottera i M. Wetherell, którzy twierdzą, że „sukces badania nie jest $\mathrm{w}$ najmniejszym stopniu zależny od wielkości próbki. W tym przypadku większa próbka niekoniecznie musi wskazywać na bardziej żmudne lub bardziej wartościowe badanie" (1987: 161 [tłum. własne]).

Zebrany materiał jest wystarczający, by podjąć próbę odpowiedzi na pytanie badawcze, jakim jest rola emocji jako praktyki dyskursywnej w sytuacji skandalu politycznego. Cytowane poniżej przykłady mają na celu ukazanie mechanizmów wykorzystania emocji do budowania, utrwalania i przekazywania sieci znaczeń w sferze polityki i mimo swej - niekiedy - barwności starają się unikać zagrożenia anegdotyzmu (wybiórczości, skłonności do przykładów spektakularnych, przed którymi przestrzega D. Silverman 2007: 40, 242-243). Ich analiza przy użyciu kategorii pragmatyki językowej i retoryki w perspektywie krytycznej analizy dyskursu ma unaocznić możliwość instrumentalnego posługiwania się różnymi typami emocji do realizacji celów związanych z walką o dominację na scenie politycznej. Tak widziane badanie i korpus, na którym się ono opiera, sprawiają, iż celowe wydaje się połączenie jakościowej analizy materiału z perspektywy krytycznej analizy dyskursu przy pomocy narzędzi zaczerpniętych z lingwistyki z szerszą refleksją nad natura, mechanizmem i konsekwencjami skandalu w życiu politycznym, źródłami jego mocnego zakorzenienia w "rytualnym chaosie" sfery publiczne (por. Czyżewski, Kowalski, Piotrowski 1997).

Zaletą materiału badawczego pochodzącego z szeroko pojętej prasy jest niewątpliwie jego dostępność i niezależność od badacza, większa niż w przypadku wywiadu czy ankiety. Trzeba sobie jednak zdawać sprawę z pewnej słabości, jaka wiąże się z materiałami prasowymi: stanowią one wycinkowy obraz rzeczywistości, wyselekcjonowany i przetworzony przez dziennikarza na potrzeby danego artykułu. Jednakże, pomijając trudności techniczne z dostępem do pełnych, bezpośrednich rejestracji wypowiedzi polityków, trzeba też pamiętać, iż dyskurs w sferze publicznej realizowany jest głównie za pośrednictwem mediów i w znacznej mierze właśnie takie wyselekcjonowane przez dziennikarzy fragmenty wypowiedzi tworzą go i kształtują.

Warto ponadto zaznaczyć, iż badaniu poddane zostały wypowiedzi zarówno zwolenników, jak i przeciwników politycznych Silvio Berlusconiego, a dalsze rozważania wykażą związek pomiędzy reprezentowaną opcją polityczną a rodzajem i funkcją emocji ujawnianych w wypowiedziach.

\section{Skandal}

Zrozumienie wagi, jaką odgrywają emocje w przypadku skandalu, co więcej, ich nieodłączności wynikającej z natury tego zjawiska, wymaga zatrzymania się nad skandalem samym $w$ sobie i mechanizmem jego powstawania współcześnie. Dzięki temu możliwe stanie się wykazanie, że emocje są immanentnym elementem skandalu jako formy walki politycznej. Emocje, te deklarowane i wyrażane publicznie, stanowią jedno z podstawowych narzędzi uprawiania polityki.
Czym więc jest skandal? Sięgając po definicje J. B. Thompsona (2010: 28), pojęcie skandalu odnosi się do działań lub wydarzeń stanowiących naruszenie pewnych norm. O naruszeniach tych dowiadują się inni ludzie. Są one na tyle poważne, że wywołują reakcję opinii publicznej. Jak widać, skandal jest $e x$ definitione sytuacja, w której dochodzi do naruszenia pewnego porządku, powszechnie aprobowanych zasad. Według Thompsona istnieją trzy obszary, które szczególnie łatwo stają się treścią skandalu, chodzi tu przede wszystkim o sferę seksualną, finansową oraz sferę władzy. Przykład skandalu Berlusconi-Ruby pokazuje, iż te trzy typy skandalu nie są rozłączne, a dane wydarzenie może rozgrywać się na każdym z tych trzech planów: $w$ tym wypadku poruszenie wzbudził zarówno niezgodny z tradycyjną moralnością tryb życia premiera, wątek hojnego opłacania rozrywek, jak i element wykorzystania swojej uprzywilejowanej pozycji wynikającej z pełnionej funkcji oraz faktycznych prerogatyw z niej wynikających do prywatnych, kontrowersyjnych celów.

Polityczny charakter skandalu z Ruby wynika z naruszenia przez Berlusconiego zasad sprawowania władzy w systemie demokratycznym, w którym równie ważny jak efekty, obserwowalne rezultaty władzy jest sposób jej sprawowania, przejrzystość procedur politycznych. Berlusconi próbował z mocy sprawowanej funkcji wpłynać na korzystne dla siebie i Ruby decyzje organów państwa (policji), wykorzystywał również urząd do budowania pozycji w życiu prywatnym. Nadwyrężenie granicy pomiędzy prywatnym i publicznym, uczciwym i niezgodnym z przepisami stanowi działanie polityczne obniżające jakość władzy; w świetle kategorii throughput legitimacy (Scharpf 1999) osłabia to legitymację do sprawowania władzy państwowej, która powinna opierać się na przejrzystości proceduralnej, jasności zasad podejmowania decyzji, dostępie do informacji i jakości relacji między aktorami życia społecznego.

Z kolei, z punktu widzenia pragmalingwistyki, owo zaburzenie, wystąienie przeciwko obowiązującym normom, które stanowi podstawę wybuchu skandalu, nie jest wystarczającym powodem, by można było o nim mówić. Aby daną kontrowersyjną sytuację określić tym mianem, konieczne jest dopełnienie pewnych warunków fortunności aktu komunikacyjnego (por. Austin 1962: 25-38): uczestnikami skandalu politycznego są osoby związane ze sferą instytucji państwa i sprawowania władzy, istnieja pewne normy społeczne, obyczajowe, które zostały naruszone, natomiast kluczowy jest element publicznego wyrażenia dezaprobaty dla zaistniałych faktów przez pewne osoby, szczególnie poruszone sytuacją. Upublicznienie krytycznej opinii na przykład przez innych uczestników życia politycznego, tak by mogła zostać odebrana przez szerokie audytorium i wywrzeć wpływ na jego członków, jest warunkiem koniecznym, by daną sytuację zaklasyfikować jako skandal.

Jak widać, rola mediów pozwalających na masowy przekaz jest $\mathrm{w}$ przypadku skandalu nie do przecenienia, umożliwiają one bowiem rozpowszechnienie informacji o gorszącym zajściu, jak i reakcji nań, na skalę do niedawna niewyobrażalną. Media są niezbędne do wybuchu skandalu, a następnie podsycania go kolejnymi doniesieniami.

Globalna wioska Marshalla McLuhana (2004), powstała dzięki nadejściu potężnego telewizyjnego medium, współcześnie coraz intensywniej poddawana jest oddziaływaniu nowych mediów, Internetu, co $\mathrm{w}$ efekcie prowadzi do zatarcia barier geograficznych i czasowych. Wpływ nowych technologii komunikacyjno-informatycznych wiąże się zatem z - jak 
nazywa to John B. Thompson (2010: 51) - przekształceniami widoczności. $\mathrm{W}$ tradycyjnym, niezmediatyzowanym społeczeństwie wiedza o innych, w tym o politykach, uzależniona była od uwarunkowań przestrzennych: widoczność wymagała współobecności. Czyny, w tym prywatne, uczestników życia publicznego mogły wyjść na jaw tylko w przypadku zaobserwowania ich przez innego członka społeczności. Obecnie w epoce medialnej widoczność, jawność zostały całkowicie oderwane od współobecności, media pozwalają na ujawnienie skandalu niezależnie od ograniczeń przestrzennych czy czasowych, zapewniają informacjom zasięg ponadlokalny. Co więcej, utrwalone przez media fakty mają dłuższy żywot niż informacje przekazywane ustnie w obrębie pewnej grupy.

Aktywna rola mediów w przypadku skandali politycznych nie ogranicza się wyłącznie do zapewnienia technicznych warunków do wybuchu skandalu, wywierają one bowiem znacznie szerszy wpływ na treści, formy, sposoby komunikowania i postrzegania rzeczywistości. $\mathrm{W}$ tym miejscu pragnę jedynie wspomnieć, iż szeroko badana mediatyzacja życia publicznego, w tym polityki, zjawisko infotainment (np. Mrozowski 2001; McQuail 2007; Kolczyński, Mazur, Michalczyk 2009) widziane są jako źródła sensacjonalizacji przekazu: przekaz ma silnie angażować widza emocjonalnie, dać prymat emocjonalności nad racjonalnością. Uwagi te doskonale wpisują się w refleksję nad funkcją mediów w powstawaniu i rozwoju skandali politycznych: można powiedzieć, że po części to natura mediów masowych sprawia, iż walka o władzę, której formą jest skandal, rozgrywa się w znaczącym stopniu w sferze emocji, a nie na poziomie kompetencji i merytorycznej wiedzy.

Omówiony powyżej aspekt publicznie, a zwłaszcza medialnie, wyrażonej dezaprobaty jako niezbędnej części składowej skandalu pozwala przejść do właściwego tematu tego artykułu, czyli funkcji emocji w sytuacji skandalu. Nie ulega wątpliwości, że to emocje sa jeśli nie motorem (nie miejsce tu na analizy autentycznych motywacji psychologicznych), to przynajmniej narzędziem, materiałem, z którego konstruowane są te krytyczne wystąpienia. Nie rozstrzygamy, czy w przypadku działalności politycznej, rządzącej się swoimi prawami skoncentrowanymi na zdobyciu poparcia i pokonaniu przeciwników emocje są rzeczywiście odczuwane, czy tylko deklarowane i tym samym wykorzystywane instrumentalnie do budowania własnego wizerunku i walki z rywalami politycznymi.

\section{W jaki sposób emocje stają się narzędziem walki politycznej w sytuacji skandalu?}

Zgodnie z tym, co zostało stwierdzone powyżej, emocje odgrywają zasadniczą rolę w życiu politycznym, gdyż mogą być wykorzystane do kreowania pozytywnego wizerunku własnej osoby, a także do zniszczenia przeciwnika politycznego. Wzmacniają one wydźwięk wypowiedzi, przekazują jednoznaczne wartościowania i oceny, $\mathrm{w}$ trudny do zanegowania sposób narzucają określony sposób postrzegania rzeczywistości.

Emocje w dyskursie politycznym stanowią narzędzie służące do realizowania pewnego z góry określonego celu perswazyjnego, jakim jest wzbudzenie pozytywnego nastawienia do siebie potencjalnego wyborcy i pogrążenie $\mathrm{w}$ jego oczach przeciwnika. Perswazja jest właściwie jedyną możliwą drogą do osiągnięcia założonego celu $\mathrm{w}$ świecie rządzonym demokratycznie. O ile $\mathrm{w}$ systemach totalitarnych władza polityczna sprawowana jest przy pomocy siły, przemocy, o tyle demokracje liberalne musza stosować inne metody zdobywania i utrzymywania władzy (Thompson 2010). Obowiązujący system prawny, autonomia prasy jako czwartej władzy, a przede wszystkim wolne wybory sprawiają, iż to nie siła jest źródłem przewagi, lecz inny rodzaj kapitału, ściśle związany z reputacją danego uczestnika życia politycznego. Nawiązując do słynnych rozważań Maxa Webera (1989) na temat polityki jako zawodu i powołania, Thompson (2010) w swej analizie legitymizacji władzy sprawowanej przez państwo dostrzega właśnie dwie jej formy: z jednej strony jest to wspomniana już władza przymusu, z drugiej władza symboliczna. Thompson rozumie ją jako zdolność wpływania na przebieg wydarzeń, na działania i przekonania innych za pomocą przekazu form symbolicznych.

Nie sposób uniknąć tutaj bezpośredniego odniesienia do teorii francuskiego socjologa Pierre'a Bourdieu (Bourdieu, Passeron 2006), ojca takich pojeć, jak właśnie władza symboliczna (przemoc symboliczna), pole władzy, kapitał symboliczny. Stosując terminy stworzone przez Bourdieu, a zapożyczone przez Thompsona, do analizy władzy politycznej w kontekście skandalu politycznego, należy podkreślić, że władza symboliczna, rozumiana jako nie do końca uświadomiony przez odbiorcę przekaz wzorów zachowań, treści, form, znaków danej kultury wraz z ich apriorycznym wartościowaniem, jest podstawową formą funkcjonowania w demokracji liberalnej. Władza symboliczna sprawowana jest przy pomocy różnego rodzaju zasobów stanowiących kapitał symboliczny, wśród których Thompson szczególną rolę przypisuje umiejętnościom, kompetencjom, wiedzy, ale także reputacji, nagromadzonemu prestiżowi i uznaniu. Reputacja, jako jedna z form kapitału symbolicznego, jest wartością, która pozwala na dojście do władzy i jej utrzymanie, przez co staje się głównym narzędziem rywalizacji, ale jednocześnie jest zasobem, który w krótkim czasie można łatwo utracić. Jak mówi Thompson:

[z]dolność polityków do sprawowania władzy symbolicznej zależy, między innymi, od znajdującego się $\mathrm{w}$ ich dyspozycji kapitału symbolicznego, czyli zgromadzonego prestiżu, reputacji i szacunku. Politycy są zatem szczególnie podatni na wszystko to, co grozi osłabieniem lub zmniejszeniem zasobów ich kapitału symbolicznego, ponieważ może to osłabić lub podkopać ich zdolność do sprawowania władzy politycznej. (2010: 131-132)

Przywołane słowa stanowią wystarczające, jak się zdaje, wyjaśnienie znaczenia, jakie ma skandal w systemie demokratycznym i jak wielką rolę odgrywa on na scenie politycznej, gdzie każda kontrowersja może pomniejszyć kapitał symboliczny pozostający w dyspozycji danego polityka, pociągnąć za sobą przegraną w kolejnych wyborach i utratę władzy. Skandal godzi w dobre imię polityka, reputacje, jaką cieszy się on wśród wyborców, a która stanowi legitymizację do sprawowania przez niego władzy. Jeśli przypomnimy sobie, iż istotą skandalu jest publicznie wyrażona dezaprobata, powodowana bądź napędzana dodatkowo emocjami, zrozumiemy, jak istotnym narzędziem walki politycznej są emocje.

Wypowiadając swą krytyczną opinię, dany uczestnik życia politycznego korzysta z mocy, której przydają jego wypowiedzi emocje, aby przekazać opinii publicznej pożądane wartościowanie sytuacji i innych aktorów politycznych, a tym samym wpłynąć na jej poglądy oraz decyzje wyborcze. Odpowiednio wyrażane emocje mogą stać się ważnym narzędziem w kształtowaniu wizerunku swojego i szkodzeniu reputacji przeciwnika, skutecznie bowiem wzmacniają siłę i element oceny wypowiedzi.

Odpowiednia organizacja semantyczna, retoryczna i pragmatyczna wypowiedzi sprawia, iż język jest 
skutecznym nośnikiem ideologii i medium interakcji, natomiast nie jest celem samym w sobie, jest narzędziem poznania, interpretowania i kształtowania rzeczywistości. Szczególnie istotne okazują się uwarunkowania kulturowe wytwarzania dyskursu (por. van Dijk 2001: 7), co w przypadku skandalu politycznego skłania do postrzegania go $\mathrm{w}$ kontekście zmian cywilizacyjnych w świecie zachodnim w obrębie moralności, wyznawanych wartości, norm społecznych (por. też Nijakowski 2008).

Niepozbawione uzasadnienia jest $\mathrm{w}$ tym kontekście odwołanie się również do aparatu pojęciowego podejścia dramaturgicznego w socjologii, reprezentowanego zwłaszcza przez Ervinga Goffmana (2006; 2008) w celu lepszego powiązania trzech podstawowych dla tego tekstu pojęć: skandalu, emocji i władzy. Wydaje się, że do opisu aktywności politycznej szczególnie przydatna może być koncepcja interakcji międzyludzkich jako swego rodzaju przedstawień teatralnych. Metafora przedstawienia zakłada istnienie aktorów (politycy i inni uczestnicy życia politycznego), sceny (nomen omen scena polityczna) oraz samego przedstawienia (działalność polityczna), w czasie którego aktorzy odgrywają przygotowane i dopracowane przez siebie role, tak by wywrzeć zamierzone wrażenie. Publicznie aktorzy (politycy) starają się ujawnić tylko to, co chcą zaprezentować, rzeczy niekorzystne, nie na miejscu pozostawiając za kulisami. Warto $\mathrm{w}$ tym miejscu podkreślić, iż zdaniem Goffmana (2006) jednostki nie są tylko i wyłącznie aktorami, którzy ślepo odgrywają swoje role narzucone przez kulturę, są też strategami, którzy manipulują ekspresją gestów, by zaprezentować się w określony sposób (Turner 2009: 43). Aktorzy, a więc i politycy, są w stanie zarządzać swoimi reakcjami, $w$ tym emocjonalnymi, $\mathrm{z}$ uwzględnieniem oczekiwań, jakie w tym względzie ma kultura danego społeczeństwa; można mó- wić o pewnych fasadach emocjonalnych konstruowanych na potrzeby widzów tak, by spełnić ich oczekiwania, zaprezentować się w pozytywny sposób i wkraść się w ich łaski. W przypadku skandalu publicznie wyrażana dezaprobata stanowi właśnie takie strategiczne przedstawienie emocji zgodnych z oczekiwaniami danego porządku kulturowego. Odpowiednia ekspresja emocji może przysłużyć się zaprezentowaniu się w pożądany sposób, a z drugiej strony przyczynić się do naruszenia pozytywnego wizerunku przeciwnika politycznego.

Mówiąc o dobrym imieniu, wizerunku, reputacji, o które trwa nieustanna walka na scenie politycznej, a skandal jest jej instrumentem, nie sposób nie odnieść się do pojęcia twarzy, stworzonego przez Ervinga Goffmana (2006).

Twarz to obraz własnego Ja naszkicowany w kategoriach uznanych atrybutów społecznych (Goffman 2006: 6), własny pozytywny wizerunek, wytworzony zgodnie ze społecznymi oczekiwaniami, który chcemy utrzymać. Według nomenklatury Goffmana można mówić o dbałości o twarz przy pomocy różnych technik twarzy, które mają na celu jej zachowanie. W odniesieniu do zabiegów aktorów politycznych dbanie o twarz oznacza ni mniej ni więcej ochronę własnej reputacji, a niejako rewersem tych działań jest dążenie do narażenia przeciwnika politycznego na utratę twarzy, czyli dobrego imienia, na kompromitację ${ }^{1}$.

${ }^{1}$ Praktyka życia codziennego wydaje się pokazywać, iż bez względne zasady gry politycznej pozwalają na zagrożenie czyjejś twarzy w imię zdyskredytowania rywala w oczach wy borców, co stoi w wyraźnej sprzeczności z regułami opisanym przez Goffmana. Goffman (2006: 10-11) twierdzi, że uczestnik każdej grupy społecznej jest zobowiązany mieć szacunek do innych jej członków i chronić również ich twarz, a bycie świadkiem czyjejś kompromitacji uznane jest za nieprzyjemne. Wyda je się, że ta pozorna sprzeczność wynika z faktu, iż w ujęciu Goffmana wzajemna ochrona twarzy jest warunkiem interakcji,
podczas gdy na scenie politycznej chodzi raczej o rywalizację.
Ten aparat interpretacyjny wyznaczony przez koncepcję kapitału symbolicznego, który w demokracji liberalnej stanowi jedyną wręcz kartę przetargową w rozgrywce o władzę oraz podejście dramaturgiczne, dzięki któremu można rozpoznać i nazwać zabiegi związane z ochroną twarzy, gromadzeniem prestiżu i szacunku, pokazuje przede wszystkim celowość działań podejmowanych przez aktorów społecznych, pozwala dostrzec ich świadomość w zakresie ujawniania swych reakcji. Krótko mówiąc, możemy zdać sobie sprawę z pewnej celowej, strategicznej manipulacji ujawnianiem własnych emocji. Emocje stają się tu narzędziem: zostają wzbudzone i wyrażone, aby doprowadzić do wybuchu skandalu, który z kolei jest formą walki o władzę rozgrywanej na polu wizerunku.

\section{Funkcja emocji w komunikacji politycznej}

Choć stopień w jakim emocje przenikają współczesny dyskurs polityczny jest wyjątkowy ze względu na przemiany, jakie przeszła komunikacja pod wpływem telewizji i nowych mediów, to jednak sama obecność emocji w komunikacji politycznej nie jest niczym nowym. Już w czasach starożytnych emocje były chętnie wykorzystywanym narzędziem polityki, a szerzej: jednym ze środków pozostających do dyspozycji mówcy. Zagadnieniu temu Arystoteles poświęcił Księgę II Retoryki, analizując 3 sposoby przekonania do siebie i swoich tez audytorium, do których może uciec się orator. Są to ethos, pathos i logos (por. Ziomek 1990: 31, 36). Logos odnosi się do elementu racjonalnego i dotyczy sfery argumentacji zawartej w wypowiedzi, ethos związany jest $z$ postacią oratora i jego charakterem, obejmuje cechy mówcy, jego postawę, zachowania, zdolność do wzbudzenia zaufania, przekonania odbiorców. Pathos z kolei odnosi się do emocji widowni i rozumiany jest jako spektrum uczuć, afektów, które jest w stanie wywołać orator swoją mową i które potrafi wykorzystać do zrealizowania założonych przez siebie celów.

Arystoteles docenia tym samym wagę nastawienia psychicznego słuchaczy i analizuje uczucia, takie jak gniew, zemsta, wzgarda, lęk, miłość, nienawiść, nadzieja, zazdrość, pod względem ich przydatności retorycznej. W jego mniemaniu dobry mówca powinien potrafić pokierować emocjami audytorium na własny użytek i podaje sposoby wywołania u widowni poszczególnych emocji (Pratkanis, Aronson 2003: 46-62).

Uwagi Arystotelesa brzmią szczególnie aktualnie współcześnie, gdy to zarządzanie emocjami, a nie racjonalną argumentacją, okazuje się kluczowe, a pathos, emocje odbiorcy, są traktowane użytkowo jako narzędzie walki politycznej.

Odwołanie się do Arystotelesa wymaga wyraźnego nazwania celu, jakiemu służą wspomniane powyżej trzy techniki, w tym pathos, a więc perswazji. Emocje, obok postawy moralnej mówcy i argumentacji, stanowią potężny środek perswazyjny, stąd ich częste wykorzystanie w komunikacji politycznej, która z definicji podporządkowana jest funkcji perswazyjnej (Walczak 1994; Dobek-Ostrowska, Fras, Ociepka 1999; Fras 2005). Taki stan rzeczy spowodowany jest przez podstawowe cele, które stawiają sobie politycy, współtworząc dyskurs polityczny: pragną stworzyć pozytywny wizerunek swojej osoby, wzbudzić przychylność audytorium dla siebie i prezentowanych przez siebie opinii, tak by przełożyło się to na korzystny wynik wyborczy, a jednocześnie osłabić pozycję przeciwników politycznych. 
Wymiar perswazyjny komunikacji politycznej dostrzeżony już w starożytności wciąż nie traci na aktualności, podobnie jak trafne uwagi na temat roli emocji w języku polityki Stanisława Barańczaka (1983: 33-35), pierwotnie odnoszące się do peerelowskiej nowomowy, które nadal sprawdzają się przy analizie współczesnego dyskursu politycznego. Według Barańczaka jednym z podstawowych sposobów realizacji funkcji perswazyjnej $\mathrm{w}$ wypowiedzi, czyli takiego jej skonstruowania, by pośrednio, a nie pod przymusem, uzyskać realny wpływ na sposób myślenia lub postępowania odbiorcy, jest emocjonalizacja odbioru. Mechanizm ten polega na maksymalnym zaangażowaniu emocjonalnym słuchacza, wywołaniu i spotęgowaniu przeżywanych przez niego uczuć, tak by osłabić jego zdolność racjonalnego myślenia i sprawić, że refleksja intelektualna ustąpi miejsca emocjonalnemu przeżywaniu rzeczywistości. Cel ten osiągany jest różnymi środkami, w tym językowymi, nasycona emocjonalnie wypowiedź, przekazująca deklaratywnie odczuwane przez niego uczucia, ma przyczynić się do „zarażenia” nimi odbiorcy.

\section{Typy emocji, językowe sposoby ich} wyrażania oraz ich wymiar dyskursywny na przykładzie skandalu Berlusconi-Ruby

Skandal Berlusconi-Ruby odbił się szerokim echem na całym świecie, między innymi ze względu na intensywność reakcji, jakie wzbudził, zapewne proporcjonalną do charakteru zajść, które go wywołały. Posłuży on tutaj jako materiał badawczy do analizy sposobów wykorzystania emocji w rywalizacji politycznej w sytuacji skandalu, z której wnioski, jak sądzę, będą mieć wymiar bardziej uniwersalny.
Jak wspomniano powyżej, uprawianie polityki polega w głównej mierze na posługiwaniu się językiem, a walka o zdobycie i utrzymanie władzy politycznej w systemie demokratycznym odbywa się w sferze komunikacji. Stąd komunikacja ta ma wymiar przede wszystkim perswazyjny; politycy mówią, aby przekonać: do siebie, do swojej partii, do prezentowanych opinii i programów. Na drodze komunikacji toczą się zmagania o zdobycie i utrzymanie kapitału symbolicznego stanowiącego jedyną obecnie legitymację do sprawowania władzy, a którego główną częścią składową jest reputacja. Lapidarnie rzecz ujmując, politycy $\mathrm{w}$ dyskursie politycznym starają się wykreować pozytywny wizerunek samych siebie i/lub zniszczyć cudzą reputację. Emocje w tak postrzeganym dyskursie politycznym mają charakter instrumentalny, dodając siły oddziaływania wypowiedziom i przekazując ładunek wartościujący.

Jakie zatem emocje stają się narzędziem walki o reputację? Z analizy wypowiedzi uczestników włoskiego życia politycznego (polityków, dziennikarzy, działaczy partyjnych) wynika, iż rodzaj ujawnianych emocji zależy od miejsca zajmowanego przez mówiącego na scenie politycznej, od jego przynależności partyjnej.

W sytuacji omawianego skandalu szczególnie chętnie ujawnianą emocją wśród przeciwników Silvio Berlusconiego jest oburzenie. Emocja ta ujawnia się w licznych wypowiedziach o różnej sile illokucyjnej. W oparciu o koncepcję Austina można wyróżnić następujące typy aktów mowy, w których ładunek emocjonalny oburzenia wykorzystywany jest do wzmocnienia siły komunikatu: krytyka, oskarżenie, dyskredytacja. Wypowiedzi tego typu wyrażają z całą mocą dezaprobatę dla czynu będącego przedmiotem skandalu, a którego upublicz- nienie ma wzbudzić w bohaterze skandalu wstyd. Ekspresja oburzenia stanowi par excellence formę publicznego wyrażenia dezaprobaty, które jest konieczne, by w ogóle można było mówić o skandalu i wpisuje się $w$ to, co John B. Thompson nazywa „obelżywym dyskursem” (2010: 36-37). Obelżywy dyskurs może przyjąć formy o różnym stopniu nasilenia: od łagodnego, umiarkowanego zbesztania, żartobliwej dezaprobaty, aż po niepohamowane oburzenie moralne.

Celem wyrażenia oburzenia jest uruchomienie pewnego mechanizmu, który $\mathrm{w}$ rezultacie prowadzić ma do przekazania i - mimochodem - narzucenia odbiorcy wartościowania danej sytuacji. Stanowi początek implikowanego ciągu: skoro ktoś wyraża oburzenie, to czyny je powodujące powinny je wzbudzać, przynoszą one hańbę i wstyd, a więc kompromitują osoby, które się ich dopuściły (Thompson 2010: 36). Ekspresja oburzenia zawiera w sobie milcząco narzucone założenie, iż dany czyn, a więc i osoba, zasługują na potępienie. Skala oburzenia ma na celu proporcjonalne podkreślenie stopnia naruszenia norm, jakiego dana osoba się dopuściła. Wszystko to służy wyręczeniu audytorium w wysiłku samodzielnej oceny sytuacji, nasycenie emocją ma skłonić do bezrefleksyjnego przejęcia danej interpretacji i narzucić określone wartościowanie. Nie zaskakuje fakt, że ocena, jaką niesie ekspresja oburzenia, jest bezwzględnie negatywna i w założeniu mówiącego powinna przyczynić się do zniszczenia reputacji autora skandalu.

Przyjrzyjmy się kilku przykładom tego mechanizmu i językowym wykładnikom, przy pomocy których jest on realizowany (tłum. przykładów własne).

Przeciwnicy Berlusconiego na scenie politycznej wypowiadali się niezwykle zdecydowanie, ucieka- jąc się do mocnych, silnie nacechowanych słów, porównań i metafor.

To naprawdę groteskowe, że zamiast przejąć się tym, że upokarza swoimi czynami Włochy, Berlusconi tylko atakuje instytucje naszego państwa, grożąc retorsjami i mówiąc kolejne kłamstwa. Powinien się wstydzić. [Anna Finocchiaro (Partito Democratico)] ${ }^{2}$

Jak widać, oburzenie parlamentarzystki wyrażone $\mathrm{w}$ tej wypowiedzi, już w swej strukturze składniowej zawierającej ocenę (to [...] groteskowe, że [...]), wzmocnione jest przy pomocy mocno wartościujących środków językowych. Pojawiają się leksemy silnie negatywnie wartościujące denotowane zachowania - „upokarzać" (wł. umiliare), „groteskowe” (wł. grottesco), premier mówi „kłamstwa” (wł. bugie), $\mathrm{w}$ dodatku nie pierwszy raz, jak implikuje przymiotnik „kolejne” (wł. ennesime). Wypowiedź kończy się sugestią co do pożądanej postawy premiera $\mathrm{w}$ tej sytuacji, przedstawionej za pomocą modalności deontycznej wyrażonej czasownikiem „powinien". Wszystkie te elementy narzucają określoną, negatywną ocenę zajść, nie pozostawiając odbiorcy miejsca na domysły.

Patetyczny ton, który pojawił się w powyższym fragmencie (określenia personifikujące kraj - „upokarza Włochy" (wł. umilia l'Italia), obecny jest również tutaj:

[t]elefon premiera na policje $\mathrm{w}$ Mediolanie $\mathrm{w}$ celu wywarcia nieuprawnionej presji to bardzo poważna sprawa. Czujemy się w obowiązku przeprosić prezydenta Egiptu Mubaraka za niegodne zachowanie Berlusconiego. [Leoluca Orlando (Italia dei Valori)] $]^{3}$

${ }^{2}$ Silvio Berlusconi contro i pm: 'Devono essere puniti' [dostęp 28.03.2011]. Dostępny w Internecie http://politica.excite.it/ silvio-berlusconi-contro-la-magistratura-N62689.html

${ }^{3}$ Più prudenza Cav. Da Bersani a Confalonieri, le reazioni allo scan${ }^{3}$ Più prudenza Cav. Da Bersani a Confalonieri, le reazioni allo scan-
dalo [dostęp 28.03.2011]. Dostępny w Internecie shtt://www. lettera43.it/politica/1863/piu-prudenza-cav.htm. 
Nie dość, że mamy tu jednoznacznie negatywną ocenę całej sytuacji („bardzo poważna” [wł. gravissima]), to $\mathrm{w}$ dodatku ogrom tego wykroczenia sprawia, iż nawet przeciwnicy polityczni czują się zobowiązani do przeprosin. Stwierdzenie to stanowi również sugestię, iż sam premier nie poczuwa się do tego, a więc jest niewychowany / zadufany w sobie, jednym słowem niegodny sprawowanej funkcji.

\section{Podobną myśl wyraża poniższy cytat:}

[n]asz kraj ma poważne problemy [...] zasługuje na premiera, który będzie $\mathrm{w}$ stanie reprezentować go z godnością i umiarkowaniem i na parlament, który nie będzie zażenowany prywatnymi sprawami premiera. [...] Niech Berlusconi poda się do dymisji. [Pier Luigi Bersani (Partito Democratico) $]^{4}$

Skoro kraj zasługuje na odpowiedniego premiera, to znaczy, że obecny taki nie jest, $\mathrm{w}$ dodatku swoim zachowaniem wywołuje zażenowanie. Nie jest to stwierdzenie pasujące do polityka o dobrej reputacji, pozwalającej na sprawowanie władzy, a raczej asercja, mająca narzucić ocenę niekorzystną dla premiera i jego dobrego imienia. Wypowiedź kończy się apelem do Berlusconiego: dymisja jest przedstawiona jako jedyne możliwe rozwiązanie sytuacji.

[m]yśleliśmy, że Berlusconi już nas nie zdziwi po niekończących się gafach, wulgaryzmach, obsesjach, świadectwach złego smaku. Ale plemienne tańce w Arcore i telefony na policję wykraczają poza wszelkie wyobrażenia [...] Obrażają i pograżają nasz kraj, jego instytucje i obywateli. [Claudio Fava (Sinistra e Libertà)] ${ }^{5}$

Powyższy cytat stanowi dość dosadny, bezpośredni atak na reputacje Berlusconiego. Jego zachowanie opisane jest przy pomocy negatywnie wartościują-

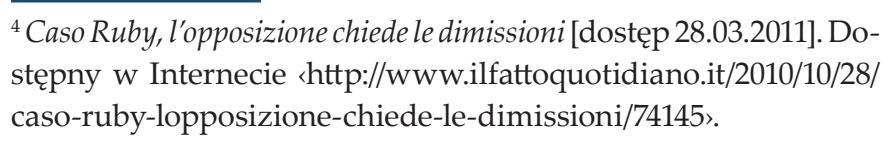

${ }^{5}$ Tamże. cych leksemów o dużej mocy: „gafy” (wł. gaffes), „wulgaryzmy" (wł. volgarità), „obsesje" (wł. ossessioni), dodatkowo mamy tu element szyderstwa - „plemienne tańce" (wł. danze tribali). Co więcej, czyny te ocenione są też wprost jako te, które obrażaja pogrążają kraj, wykraczają poza wszelkie wyobrażenia.

Kolejne przykłady stanowią potwierdzenie powyżej opisanych sposobów ekspresji oburzenia, można tu zaobserwować również leksemy odnoszące się do nieprzyjemnych emocji, których źródłem jest postępowanie premiera (wstyd, upokorzenie) oraz zleksykalizowane metafory (okrywać błotem, wymierzać policzek) ubarwiające przekaz, dodające mu ekspresywności, a przez to zwiększające jego siłę oddziaływania:

[j]ako Włosi odczuwamy głęboki wstyd z powodu tego, co ujawniło mediolańskie śledztwo na temat Silvio Berlusconiego [...]. Zachowanie premiera to nieustanne policzki wymierzane obywatelom [...], niech Berlusconi poda się do dymisji i przestanie okrywać błotem instytucje państwa. [Angelo Bonelli (I Verdi)]

To, co wynika z ostatnich informacji na temat skandalu Berlusconi-Ruby, pokazuje upokarzający obraz sytuacji dla osób w niego zamieszanych, a przede wszystkim dla całego kraju. [Maurizio Migliavacca (Partito Democratico) $]^{7}$

Innym przykładem przydawania wypowiedzi mocy i malowniczości, które pobudzają odbiorcę i ułatwiają mu recepcję komunikatu, są barwne porównania:

${ }^{6}$ Ruby, opposizione all' attacco: „Premier a casa” [dostęp 28.03.2011] Dostępny w Internecie chttp://www.ilgiornale.it/interni/ruby opposizione_allattacco_premier_casa/politica-berluscon2011/articolo-id=500105-page $=0$-comments $=1$.

7 Caso Ruby, il Pd: "Vicenda umiliante per il Paese" [dostęp 28.03.2011]. Dostępny w Internecie 'http://tg24.sky.it/tg24/politica/201//1/17/ruby_bunga_bunga_silvio_berlusconi_intercettazioni_carte_pm_reazioni_politiche.html. [w] porównaniu z Berlusconim Kaligula był moralistą [...]. [Massimo Donadi (Italia dei Valori)] ${ }^{8}$

Lub pozornie wyrażane współczucie i zrozumienie, które kryją krytykę:

[o]bsesja, którą ujawnia, jest typowa dla zaburzenia narcystycznego osobowości, które prowadzi do zaburzonego postrzegania rzeczywistości: osoba z takimi problemami jest $\mathrm{w}$ trudnej sytuacji i należy jej pomóc, Berlusconi jest słaby i podatny na szantaż. [Ignazio Marino (Italia dei Valori) $]^{9}$

Wart zauważenia jest sposób wykorzystania emotywizacji wypowiedzi jako techniki perswazyjnej $\mathrm{w}$ połączeniu $\mathrm{z}$ innymi tego typu zabiegami, jak na przykład użycie presupozycji (Grice 1980). Presupozycje, czyli uprzednio istniejące sądy, niewypowiedziane wprost, których przyjęcie jest konieczne, by dane zdanie miało jakąś wartość logiczna, są wyraźnie widoczne w powyższych przykładach. Gdy na przykład posłanka Finocchiaro wypowiada słowa: „zamiast przejąć się tym, że upokarza swoimi czynami Włochy, Berlusconi tylko atakuje instytucje naszego państwa", narzuca jednocześnie, nie wprost, założenie, iż Berlusconi rzeczywiście upokarza kraj, jeśli A. Bonelli apeluje o dymisję, używając czasownika „przestać” („niech przestanie okrywać błotem instytucje państwa"), zawiera w swej wypowiedzi presupozycję, iż taka działalność do tej pory miała miejsce. Ten pragmatyczny zabieg w połączeniu $z$ silnie nacechowanymi emocjonalnie i oceniająco leksemami stanowi o wielkiej sile perswazyjnego oddziaływania komunikatu.

${ }^{8}$ L'opposizione attacca il Premier, Vendola chiede dimissioni e urne [dostep 28.03.2011]. Dostepny w Internecie http://www libe[dostęp 28.03.2011]. Dostępny w Intentecie hittp://www.libeVendola-chiede-dimissioni-e-urne.htmls ${ }^{9}$ Tamże.
Z kolei z analizy komentarzy dla mediów, których udzielali zwolennicy i współpracownicy Berlusconiego, wynika, iż ich wypowiedzi były bardziej stonowane, nie odwoływały się do tak silnych emocji, jak oburzenie, dostrzec tam można raczej zrozumienie, swoistą dumę, poczucie wspólnoty. Korzystając z aparatu stworzonego przez Goffmana, zachowania te włączylibyśmy w obręb technik służących ratowaniu twarzy.

Spójrzmy na kilka przykładów:

[k]olejny atak [...], operacja, która ma doprowadzić do zmiany na stanowisku premiera. [Fedele Confalonieri (prezes Mediaset) $]^{10}$

[zalecam] ostrożność i dyskrecję w wyrażaniu swojej żywiołowości. [Vittorio Feltri (il Giornale)] ${ }^{11}$

Historia jest pełna głów państw-dziwkarzy, najbardziej znany jest John Fitzgerald Kennedy [...]. Silvio, w nocy rób, co chcesz, ale mimo ciemności miej oczy otwarte. [Maurizio Belpietro (Libero)] ${ }^{12}$

Berlusconi jest prześladowany. [Gianfranco Micciché (podsekretarz Rady Ministrów) $]^{13}$

[...] atak lewicy przeciwko Silvio Berlusconiemu na poziomie osobistym [...], Włosi widzą różnicę pomiędzy rządem, który stara się koncentrować na konkretnych sprawach a opozycją, która zajmuje się podglądaniem przez dziurkę od klucza pokojów w Arcore. [Daniele Capezzone (rzecznik Popolo della Libertà)] $]^{14}$

${ }^{10}$ Più prudenza Cav. Da Bersani a Confalonieri, le reazioni allo scandalo [dostęp 28.03.2011]. Dostępny w Internecie http:// www.lettera43.it/politica/1863/piu-prudenza-cav.htm.

${ }^{11}$ Tamże.

${ }^{12}$ Tamże.

${ }^{13}$ Tamże.

${ }^{14}$ Ruby, Maroni: "Questura ha seguito la prassi" Il premier: "Tutti contro di me ma vado avanti" [dostęp 28.03.2011]. Dostępny w Internecie $h$ http://www.ilgiornale.it/interni/ruby_maroni_qu estura_ha_seguito_prassi_iil_premier_tutti_contro_me ma_vado_avanti/cronaca-berlusconi-bersani-questura-procura_milano-ruby-annamaria_fiorillo-tribunale_minori-
netti/31-10-2010/articolo-id=483695-page $=1$-comments 6 . 
Szczególnie widoczny jest mechanizm ochrony twarzy poprzez podważenie uczciwych intencji przeciwników, ich publicznie wyrażana dezaprobata dla czynów Berlusconiego jest nazwana przy użyciu silnie ocennych rzeczowników: atak ( $w$ dodatku kolejny i o charakterze wywrotowym), prześladowanie. Innym sposobem obrony jest ośmieszanie rywali przy użyciu zmetaforyzowanych obrazów, wykorzystujących potoczność, codzienne doświadczenie jako swój budulec, czego przykładem jest tu określenie badania przebiegu skandalu jako „podglądania przez dziurkę od klucza”. Jest to próba odwrócenia sytuacji i takiego jej opisania, by to oburzeni skandalem się zawstydzili, a Berlusconi został przedstawiony jako niewinna ofiara. Oburzenie zmienia swój znak, zwolennicy Berlusconiego zamiast zawstydzenia zdają się prezentować oburzenie nieuzasadnioną krytyką. Można tu dostrzec empatię, zrozumienie dla stylu życia włoskiego premiera, wyrażające się w stosowaniu eufemizmów (żywiołowość) do opisania jego czynów czy dawaniu porad, jak się chronić.

Rozważając możliwość wykorzystania oburzenia jako narzędzia niszczenia reputacji $\mathrm{w}$ rozgrywce politycznej, zatrzymać się należy na chwilę nad powiązanym z nim wstydem. Według Susan Shott (1979) wstyd jest jedną z silniejszych emocji, która pozwala na kontrolowanie jednostek, gdyż generuje zachowania konformistyczne, podporządkowanie normom danej wspólnoty: wstyd zostaje wzbudzony u jednostki ze względu na jej wrażenie o negatywnej opinii innych na jej temat $\mathrm{w}$ związku z jakimś czynem, co z kolei stanowi atak na jej tożsamość. Poczucie wstydu skłoni w efekcie jednostkę do unikania sytuacji wywołujących tę emocję.

W kontekście rywalizacji politycznej pragnienie wywołania poczucia wstydu u przeciwnika poli- tycznego poprzez ekspresję oburzenia jego postępowaniem wiąże się bezpośrednio z chęcią skompromitowania go, zniszczenia jego pozytywnego wizerunku. Publicznie przeżywany wstyd, zmieszanie, upokorzenie wynikające $z$ lęku przed oceną innych jest przykrymi przeżyciami dla aktora, ale jednocześnie wiążą się z repulsywnymi emocjami otoczenia, które jest świadkiem nieadekwatnych zachowań członka społeczności (Górska 2009: 255).

Publiczne przeżycie wstydu wiąże się z utratą twarzy, a więc nadszarpnięciem reputacji, jej ratowanie wymaga podjęcia działań, takich jak przeprosiny, wyjaśnienia. Co ciekawe, w opisywanym przypadku mechanizm oburzenie-wstyd nie zadziałał, zabrakło efektu perlokucyjnego $\mathrm{w}$ postaci odczucia wstydu przez Berlusconiego, a sam premier odpowiedział wystąieniem telewizyjnym pełnym oburzenia i oskarżeń, twierdząc, iż cała sprawa z Ruby to spisek lewicowych prokuratorów. Można pokusic się o wyjaśnienie oparte na założeniu, iż publiczna ekspresja wstydu byłaby jednoznaczna z przyznaniem się do winy, a więc przesądziłaby o całkowitej utracie twarzy, toteż włoski premier uznał, że obrona przez atak, zareagowanie oburzeniem na oburzenie przeciwników politycznych będzie jedyną skuteczną techniką ochrony twarzy.

\section{Zakończenie}

Przyjęta w tym tekście perspektywa krytycznej analizy dyskursu pozwala zauważyć, iż stosowany język nie służy jedynie jako narzędzie komunikacyjne, lecz jego zadaniem jest wypełnienie, poprzez mechanizmy pragmatyczne, określonych zadań: narzucenie znaczeń, interpretacji, przekazanie i wywołanie pożądanych emocji prowadzących do korzystnych z punktu widzenia mówiącego wartościowań. Jak to ujmuje Nijakowski: „[j]ęzyk to narzędzie władzy, działanie społeczne i medium reprodukcji różnego typu tożsamości, a tym samym wspólnot wyobrażonych" (2008: 117).

Przedstawione powyżej powiązanie pomiędzy typem prezentowanych $w$ dyskursie politycznym emocji a formami językowymi i retorycznymi, widziane jako rodzaj strategii perswazyjnej, nie wyczerpuje zagadnienia sposobów skutecznego przekazywania i odczytywania przedstawianychidei. Wskazane powyżej zabiegi retoryczne i pragmatyczne wykorzystujące emocje do wzmocnienia przekazu, narzucenia wartościowań, przywołania norm społecznych jako sposobu sprawowania władzy stanowią jeden z etapów (por. Tomlin i in. 2001) organizacji dyskursu, a pełne spojrzenie na budowanie i odbieranie znaczenia wymaga przedstawienia mechanizmu, który pozwala na właściwą recepcję i interpretację poszczególnych komunikatów w ramach określonego dyskursu, tu politycznego. $\mathrm{W}$ tym kontekście badacze związani z krytyczną analizą dyskursu (van Dijk 1985; 1998; 2001; Fairclough 1989) proponują kategorię koherencji (coherence), która nie odnosi się jedynie do spójności formalnej tekstu, bazującej na odpowiednich relacjach pomiędzy poszczególnymi zdaniami wypowiedzi (jak mówi van Dijk [1998: 38]: ,[l]okalna koherencja pomiędzy zdaniami tekstu lub wypowiedzi jest warunkiem koniecznym, lecz niewystarczającym dla koherencji dyskursu"), lecz raczej chodzi tu o koherencję na poziomie globalnym (global coherence), która pojedyncze wypowiedzi integruje w jedną całość:

[z]akłada się zatem, że, oprócz lokalnej struktury semantycznej, dyskurs posiada również globalną strukmantycznej, dyskurs posiada również globalną struk-
turę semantyczną lub makrostrukturę [...] Makrostruktura jest więc teoretyczną rekonstrukcją takich intuicyjnie rozumianych pojęć, jak temat czy motyw dyskursu. Wskazuje ona, co jest najważniejsze, naj- istotniejsze lub najbardziej się wyróżnia w semantycznej informacji, jaką niesie dyskurs jako całość. Jednocześnie, makrostruktura dyskursu określa jego koherencję globalną. Bez koherencji globalnej nie byłoby możliwe zapanowanie nad lokalnymi powiązaniami i dalszymi ciaggami. (van Dijk 1985: 115 [ttum. własne])

Dzięki istnieniu i możliwości rozpoznania makrostruktury, odpowiedniego zorganizowania argumentów w obrębie tematu, którego dotyczy dyskurs, możliwe jest scalanie wiedzy (Tomlin $\mathrm{i}$ in. 2001: 65-68). Te pojęcia pozwalają nam zastanowić się, w jaki sposób w dyskursie będącym dynamicznym procesem dochodzi do kształtowania i rozumienia przekazu. Analizowane powyżej przykłady same $\mathrm{w}$ sobie stanowią oderwane od siebie, pojedyncze zdania, natomiast dzięki koherencji globalnej dyskursu widzimy je jako części pewnej całości, realizacje mające swoje miejsce $\mathrm{w}$ pewnej sensownej, spójnej strukturze, odwołującej się do pewnego tematu i wprowadzającej nowe cząstki informacji (por. struktura rematyczna, Tomlin i in. 2001: 80-88).

W dziedzinie dyskursu politycznego, tutaj ograniczonego do sytuacji skandalu, istnienie koherencji globalnej, możliwość rozpoznania tematu globalnego pozwala na właściwe zinterpretowanie poszczególnych wypowiedzi w kontekście zależności między typem emocjonalnej reakcji na skandal (oraz jej retorycznej i pragmatycznej formy) a przynależnością polityczną mówiącego. Tutaj scalanie wiedzy, które możliwe jest w przestrzeni pomiędzy nadawca, wybierającym pojęcia i organizującym celowo dyskurs a odbiorca, który odbiera i rekonstruuje zamierzony sens, opiera się na znajomości kontekstu sytuacyjnego, społecznego, politycznego, kulturowego. Czynniki językowe, takie jak metafory, porównania, zastosowana leksyka (a więc organizacja retoryczna dyskursu podporządkowana intencjom nadawcy), mogą być właściwie zrozumiane 
i zinterpretowane dopiero wtedy, gdy umieści się je na szerszym tle pewnego repertuaru społeczno-kulturowych przekonań, podzielanych przez grupę norm, wartości, konwencji komunikacyjnych, wiedzy i opinii (van Dijk 2001: 26-28), które stanowią organizację referencjalną dyskursu (van Dijk 2001: 49). Interesującym byłoby poddanie analizie również zestawu tych wspólnych przedmiotów odniesień i sądów, do których odwołują się mówiący, co w tym miejscu ze względu na objętość tekstu, jak i jego główny cel, którym są językowe strategie wykorzystania emocji do stworzenia i narzucenia pewnej reprezentacji pojęciowej danej sytuacji, nie jest możliwe. Co jest jednak istotne, w przypadku dyskursu politycznego niewykonalne jest zarówno badanie go, jak i uczestniczenie $\mathrm{w}$ nim z pominięciem relacji tekst - świat zewnętrzny, to znaczy bez uwzględnienia ideologii, przekonań politycznych, znajomości norm społecznych i moralnych, odniesień kulturowych, czyli, jak mówi Fairclough, niewypowiedzianych wprost założeń i oczekiwań uczestników komunikacji, na bazie których powstaje - wytwarzana w chemicznej reakcji pomiędzy tym, co „w tekście” a tym, co „w interpretatorze"koherencja tekstu (1989: 78).

Reasumując dotychczasowe rozważania, należy podkreślić, iż poddane analizie emocje, czyli oburzenie i wstyd oraz empatia/zrozumienie, nie wyczerpują spektrum emocji ujawnianych i wykorzystywanych w komunikacji politycznej.

Emocjonalizacja komunikatu jest zatem zbyt efektywną techniką perswazyjną, by politycy z niej rezygnowali, w związku z czym znaczna część przekazów politycznych wykorzystuje emocje w celu zjednania sobie słuchaczy, przekonania ich do swojej osoby i swojego programu, ale także do pogrążenia rywali w oczach wyborców. Nawet z nienau- kowej obserwacji wystąpień medialnych polityków łatwo można skonstatować, jakie emocje chętnie i stosunkowo łatwo starają się oni wzbudzić. Warto tu dla przykładu wymienić lęk i nadzieję (por. np. Cislaru 2012). Umiejętnie wywołany i sterowany strach przed prawdziwym bądź nieprawdziwym zagrożeniem ma silny walor integrujący grupę w obliczu wspólnego wroga, wspólnego problemu (Coser 2009). Wyborcy kierowani tą emocją mogą okazać się bardziej zdyscyplinowani w swych zachowaniach wyborczych, bardziej zmotywowani do działania, a także podatni na podsuwane im jednoznaczne rozwiązania. Wzbudzając wśród słuchaczy poczucie zagrożenia, polityk tworzy jednocześnie pozytywny wizerunek własnej osoby jako męża opatrznościowego z gotową receptą na wszelkie bolączki. Podobnie instrumentalnie traktowana jest nadzieja, wzbudzana i podsycana licznymi obietnicami wyborczymi, która służy zdobyciu zaufania i poparcia audytorium.

Jednak w sytuacji skandalu politycznego cele aktorów społecznych są jasno określone i sprowadzają się do bezpośredniego starcia przeciwników politycznych, w którym orężem jest reputacja. Skandal polityczny stanowi niezwykle skuteczną formę walki o władzę symboliczna, w której podstawową taktyką jest zniszczenie kapitału symbolicznego rywala, obejmującego jego dobre imię, prestiż, szacunek. Tak pojmowany kapitał jest zależny od oceny innych, a przez to niezwykle podatny na wszelkie ataki. Szczególnie dotyczy to reputacji ze względu na charakter (Thompson 2010: 309), która, w odróżnieniu od reputacji ze względu na umiejętności, jest mniej trwała, gdyż nie opiera się na wymiernych kompetencjach, lecz na opinii innych.

Publiczna ekspresja oburzenia, będąca konstytutywną częścią skandalu, ma na celu naruszenie podstaw tej pozytywnej opinii i narzucenie negatywnego wartościowania osoby, której zachowanie stało się przyczyną skandalu. Emocje zawarte w komunikacie spełniają nie tylko funkcję wartościująca, ale także służą zmianie sposobu recepcji przekazu na bardziej bezrefleksyjny, automatyczny, mniej racjonalny. Emocjonalizacja przekazu realizowana jest na poziomie językowym pod postacią wartościujących asercji, słownictwa oceniającego, porównań i metafor niosących jednoznaczną ocenę, dysfemizmów, a na poziomie pragmatycznym - poprzez krytykę, oskarżenie, dyskredytację, drwinę, apel.

Skuteczność perswazji za pomocą emocji wzmaga fakt, iż wydają się szczere, a ich ekspresja spontaniczna i podyktowana słusznymi pobudkami, przez co aspekt perswazyjny emocjonalnej wypowiedzi nie jest bezpośrednio dostępny, a - jak wiadomo najlepsze efekty odnosi przekonywanie, którego odbiorcy sobie nie uświadamiają.

\section{Bibliografia}

Austin John Langshaw (1962) How to do things with words. Oxford: The Clarendon Press.

Barańczak Stanisław (1983) Czytelnik ubezwłasnowolniony: perswazja w masowej kulturze literackiej PRL. Paryż: Libella.

Bourdieu Pierre, Passeron Jean-Claude (2006) Reprodukcja: elementy teorii systemu nauczania. Wyd. 2. Przełożyła Elżbieta Neyman. Warszawa: Wydawnictwo Naukowe PWN.

Cislaru Geaorgeta (2012) Emotions as a Rhetorical Tool in Political Discourse [w:] Maria Załęska, ed., Rhetoric and Politics: Central/Eastern European Perspectives. Cambridge: Cambridge Scholars Publishing, s. 107-126.
Tak widziane emocje są narzędziem kontroli społecznej, dającym lub odbierającym uczestnikom życia politycznego legitymację do władzy. Analiza przypadku Berlusconi-Ruby skłania do przekonania, iż stanowią one instrument walki politycznej, której częścią jest właśnie praca nad nimi: panowanie nad ekspresją. Tak jak personel pokładowy linii lotniczych, który badała Hochschild (2009), politycy muszą kontrolować swoje emocje i utrzymywać wizerunek spójny z obowiązującymi w danej kulturze regułami wyrażania oraz ideologią, którą reprezentują.

Dlatego też emocje w dyskursie politycznym mogą być traktowane instrumentalnie, co nie przesądza o ich autentyczności w wielu wypadkach, ale niewątpliwie świadome sterowanie ekspresją oburzenia może stanowić jedno z narzędzi walki politycznej - czy skuteczne, mogą pokazać jedynie demokratyczne wybory. 
----- ed. (2001) Dyskurs jako struktura i proces. Przełożył Grzegorz Grochowski. Warszawa: Wydawnictwo Naukowe PWN

Dobek-Ostrowska Bogusława, Fras Janina, Ociepka Beata (1999) Teoria i praktyka propagandy. Wrocław: Wydawnictwo Uniwersytetu Wrocławskiego.

Goffman Erving (2006) Rytuat interakcyjny. Przełożyła Alina Szulżycka. Warszawa: Wydawnictwo Naukowe PWN.

----- (2008) Człowiek w teatrze życia codziennego. Przełożyli Helena Datner-Śpiewak i Paweł Śpiewak. Warszawa: Wydawnictwo Aletheia.

Fairclough Norman (1989) Language and power. London: Longman.

Fras Janina (2005) Komunikacja polityczna. Wybrane zagadnienia gatunków i języka wypowiedzi. Wrocław: Wydawnictwo Uniwersytetu Wrocławskiego.

Goban-Klas Tomasz (2004) Media i komunikowanie masowe: teorie $i$ analizy prasy, radia, telewizji i Internetu. Warszawa: Wydawnictwo Naukowe PWN.

---- (2005) Cywilizacja medialna: geneza, ewolucja, eksplozja. Warszawa: Wydawnictwa Szkolne i Pedagogiczne.

Górska Joanna (2009) Wstyd w ponowoczesności [w:] Piotr, Binder, Hanna Palska, Wojciech Pawlik, red., Emocje a kultura $i$ życie codzienne. Warszawa: Wydawnictwo IFiS PAN, s. 253-272.

Grice Herbert Paul (1980) Logika i konwersacja [w:] Barbara Stanosz, red., Język w świetle nauki. Przełożyła Teresa Hołówka i in. Warszawa: Czytelnik, s. 91-114.

Hochschild Arlie R. (2009) Zarzadzanie emocjami: komercjalizacja ludzkich uczuć. Przełożył Jacek Konieczny. Warszawa: Wydawnictwo Naukowe PWN.

Horolets Anna (2006) Europa w polskich dyskursach. Toruń: Wydawnictwo Adam Marszałek.

Kemper Theodore D. (2005) Modele spoteczne w wyjaśnianiu emocji [w:] Michael Lewis, Jeannette M. Haviland-Jones, red., Psychologia emocji. Przełożyła Magdalena Kacmajor i in. Gdańsk: Gdańskie Wydawnictwo Psychologiczne.
Kolczyński Mariusz, Mazur Marek, Michalczyk Stanisław, red., (2009) Mediatyzacja kampanii politycznych. Katowice: Wydawnictwo Uniwersytetu Śląskiego.

Konecki Krzysztof Tomasz (2005) Jakościowe rozumienie innych a socjologia jakościowa. „Przegląd Socjologi Jakościowej", t. 1, nr 1, s. 1-3 [dostęp 20 lutego 2013]. Dostępny w Internecie: http://www.qualitativesociologyreview.org/PL/Volume1/PSJ_1_1_Editorial.pdf.

McLuhan Marshall (2004) Zrozumieć media: przedłużenia człowieka. Przełożyła Natalia Szczucka. Warszawa: Wydawnictwa Naukowo-Techniczne.

McQuail Denis (2007) Teoria komunikowania masowego. Przełożyły Marta Bucholc i Alina Szulżycka. Warszawa: Wydawnictwo Naukowe PWN.

Mrozowski Maciej (2001) Media masowe: władza, rozryw ka i biznes. Warszawa: „Aspra-Jr”.

Nijakowski Lech (2008) Mowa nienawiści w świetle teoril dyskursu [w:] Anna Horoltes, red., Analiza dyskursu w socjologii i dla socjologii. Toruń: Wydawnictwo Adam Marszałek, s. 113-133.

Potter Jonathan, Wetherell Margaret (1987) Discourse and Social Psychology: Beyond Attitudes and Behaviour. London: Sage.

Pratkanis Anthony, Aronson Elliot (2003) Wiek propagandy. Używanie i nadużywanie perswazji na co dzień. Przełożyli Józef Radzicki, Marcin Szuster. Warszawa: Wydawnictwo Naukowe PWN.

Santulli Francesca (2005) Le parole del potere, il potere delle parole. Retorica e discorso politico. Mediolan: Franco Angeli.

Scharpf Fritz W. (1999) Governing in Europe: effective and democratic? Oxford: Oxford University Press.

Searle John R. (1969) Speech acts. An essay in the philosophy of language. Cambridge: Cambridge University Press.

Shott Susan (1979) Emotion and Social Life: A Symbolic Interactionist Analysis. "The American Journal of Sociology", vol. 84, no. 6, s. 1317-1334.

Silverman David (2007) Interpretacja danych jakościowych. Przełożyły Małgorzata Głowacka-Grajper i Joanna Ostrowska. Warszawa: Wydawnictwo Naukowe PWN.
Stets Jan E., Turner Jonathan (2007) Handbook of the sociology of emotions. New York: Springer.

Szacki Jerzy (2002) Historia myśli socjologicznej. Warszawa: Wydawnictwo Naukowe PWN.

Thompson John B. (2010) Skandal polityczny: władza i jawność w epoce medialnej. Przełożył Miłosz Habura. Warszawa: Wydawnictwo Naukowe PWN.

Tomlin Russel S. i in. (2001) Semantyka dyskursu [w:] Teun A. van Dijk, red., Dyskurs jako struktura i proces. Przełożył Grzegorz Grochowski. Warszawa: Wydawnictwo Naukowe PWN, s. 45-101.

Turner Jonathan H. (2009) Socjologia emocji. Przełożyła Marta Bucholc. Warszawa: Wydawnictwo Naukowe PWN.
------ (2010) Struktura teorii socjologicznej. Przełożyła Grażyna Woroniecka i in. Warszawa: Wydawnictwo Naukowe PWN

Walczak Bogdan (1994) Co to jest język polityki [w:] Janusz Anusiewicz, Bogdan Siciński, red., Jezzyk a kultura. T. 11: Język polityki a wspótczesna kultura polityczna. Wrocław: Towarzystwo Przyjaciół Polonistyki Wrocławskiej, s. $15-20$.

Weber Max (1989) Polityka jako zawód i powołanie. Przełożyli Piotr Egel i Michał Wander. Warszawa: Niezależna Oficyna Wydawnicza.

Ziomek Jerzy (1990) Retoryka opisowa. Wrocław: Zakład Narodowy im. Ossolińskich. 